\title{
The pre-burning condition of Chalcolithic cremated human remains from the Perdigões enclosures (Portugal)
}

\begin{tabular}{|c|c|}
\hline Journal: & International Journal of Osteoarchaeology \\
\hline Manuscript ID & Draft \\
\hline Wiley - Manuscript type: & Research Article \\
\hline $\begin{array}{r}\text { Date Submitted by the } \\
\text { Author: }\end{array}$ & $\mathrm{n} / \mathrm{a}$ \\
\hline Complete List of Authors: & $\begin{array}{l}\text { Godinho, Ricardo Miguel; Universidade do Algarve, Interdisciplinary } \\
\text { Center for Archaeology and Evolution of Human Behaviour (ICArHEB) } \\
\text { Gonçalves, David; Universidade de Coimbra, Research Centre for } \\
\text { Anthropology and Health (CIAS), Department of Life Sciences; } \\
\text { Universidade de Coimbra, Laboratory of Forensic Anthropology, Centre } \\
\text { for Functional Ecology, Department of Life Sciences; Archaeosciences } \\
\text { Laboratory, Directorate General for Cultural Heritage and } \\
\text { LARC/CIBIO/InBIO } \\
\text { Valera, António; Era Arqueologia S.A., NIA, Núcleo de Investigação } \\
\text { Arqueológica; Universidade do Algarve, nterdisciplinary Center for } \\
\text { Archaeology and Evolution of Human Behaviour (ICArHEB) }\end{array}$ \\
\hline Keywords: & Bioarchaeology, Cremation, Burned bone, Funerary practice \\
\hline
\end{tabular}

\section{SCHOLARONE Manuscripts}


Title: The pre-burning condition of Chalcolithic cremated human remains from the Perdigões enclosures (Portugal).

Running title: The pre-burning condition of Chalcolithic cremains from Perdigões.

\author{
Authors \\ Godinho RM, Gonçalves D, Valera AC

\section{Ricardo Miguel Godinho} \\ Corresponding author \\ ricardomiguelgodinho@gmail.com \\ - Interdisciplinary Center for Archaeology and Evolution of Human Behaviour \\ (ICArHEB), University of Algarve, Faculdade das Ciências Humanas e Sociais, \\ Universidade do Algarve, Campus Gambelas, 8005-139, Faro, Portugal
}

\title{
David Miguel da Silveira Gonçalves
}

davidmiguelgoncalves@gmail.com

- $\quad$ Research Centre for Anthropology and Health (CIAS), Department of Life Sciences, University of Coimbra, Calçada Martim Freitas, 3000-456 Coimbra, Portugal - Laboratory of Forensic Anthropology, Centre for Functional Ecology, Department of Life Sciences, University of Coimbra, Calçada Martim de Freitas, 3000456 Coimbra, Portugal

- Archaeosciences Laboratory, Directorate General for Cultural Heritage and LARC/CIBIO/InBIO, Rua da Bica do Marquês 2, 1300-087 Lisboa, Portugal

\section{António Carlos Valera}

acvalera25@gmail.com

- Interdisciplinary Center for Archaeology and Evolution of Human Behaviour (ICArHEB), University of Algarve, Faculdade das Ciências Humanas e Sociais, Universidade do Algarve, Campus Gambelas, 8005-139, Faro, Portugal

- $\quad$ Era Arqueologia S.A., Calçada de Santa Catarina, 9C 1495-705 Cruz Quebrada, Portugal 


\begin{abstract}
The Iberian Chalcolithic displayed a remarkable variety of funerary practices, which has been related to inter-population differences, intra-population social-cultural differences and complex multistage funerary rituals. Perdigões, a Chalcolithic set of ditched enclosures, reflects such diversity including a wide array of funerary practices. Among those practices is cremation, which, despite relatively rare, is represented in different structures in Perdigões. One of these structures (Pit 40) presents an unparalleled high minimum number of individuals $(n=240)$, contrasting with nearby and coeval structures. In this study we analyse heat-induced bone changes and other archaeothanatological variables to tentatively assess the pre-burning condition of the human remains. The results of Pit 40 are also compared to other comparable contexts to assess if this unique context presents further funerary differences relative to those other contexts in, e.g, body processing. Our results suggest preferential cremation of fleshed human remains, but burning of at least a minority of skeletonised remains and deposition of possibly unburned remains also likely occurred. Body processing appears to be comparable to that of the cremation contexts of Perdigões but contrasts with that of another nearby context (Dolmen of Olival da Pega $2 b$ ) in which burned bones were also found.
\end{abstract}

Keywords: Bioarchaeology; cremation; burned bone; funerary practice. 


\section{Introduction}

Funerary practices in the Chalcolithic vary markedly in Southern Portugal and include both primary and secondary deposition of human remains in dolmens, tholoi, pits, ditches and hypogea (Valera et al. 2010). Although cremation has also been reported (Cataroche and Gowland 2015; de Becdelievre et al. 2016; de Becdelievre et al. 2015; Gatto 2007; Geber et al. 2017; Silva et al. 2015b; Silva et al. 2008), it appears to have been restricted to a relatively low number of individuals per structure/site and thus be a marginal funerary practice in recent pre-history (for a review see WeissKrejci, 2005). Such diversity in funerary practices has been related to inter-population differences (Fernández-Crespo and de-la-Rúa 2016; Fernández-Crespo and Schulting 2017; López-Onaindia et al. 2017), intra-population social-cultural differences (Fernández-Crespo and de-la-Rúa 2016; Fernández-Crespo and Schulting 2017; Fontanals-Coll et al. 2015; Valera 2017b), or complex multistage sequences of funerary rites (Hutchinson and Aragon 2002).

This topic is of acute relevance in Perdigões, a complex set of ditched enclosures in southeast Portugal that was occupied from the late Middle Neolithic to the early Bronze Age (3500-2000 BC) and which is interpreted as an aggregation centre of social-culturally differentiated groups (Valera 2017b). In Perdigões, different funerary practices coexisted, including cremation and deposition of unburned human remains in collective tombs, pits and ditches (Silva et al. 2015a; Silva et al. 2017; Silva et al. 2015b). Of particular interest in Perdigões is a circular pit (Pit 40) containing mostly cremated remains (cremains). Just next to Pit 40, associated contexts (Ambiente 1 and Cista) contain the cremated remains of many individuals (a minimum of 77 individuals; Pereira, 2015). Additionally, another nearby pit (Pit 16) in Perdigões exclusively contains the cremains of 9 individuals (Silva et al. 2015b; Valera and Godinho 2010). All these cremation contexts contrast with the remaining non-cremation funerary contexts not only in body processing but also because the funerary structures and the associated grave goods differ completely. As a result, such funerary differences have been hypothesized to relate to social-cultural differences and processes of social emulation (Valera 2017b; Valera et al. 2015). Although there are some more Neolithic/Chalcolithic funerary contexts in Portugal containing burned human remains, such as Cabeço de Moínhos (Silva et al. 2013), Eira da Pedrinha (Corrêa and Teixeira 1949), Anta das Castelhanas (Oliveira 2000) and Olival da Pega 2b (Silva et al. 2008), it is unclear whether those remains were intentionally burned as part of a funerary practice 
or burned post-depositionaly due to other non-funerary processes. As such, Pit 40, Ambiente 1, Cista and Pit 16 of Perdigões are some of the very few confirmed outdoor cremation funerary contexts from the Late Neolithic/Chalcolithic found in Portugal. Thus, it is of interest to understand the funerary rite (i.e. body processing) from Pit 40 in detail and compare it to the associated contexts (Ambiente 1 and Cista), the somewhat similar funerary rite from Pit 16 of Perdigões and to another nearby context involving burned skeletal remains that have been studied (Olival da Pega 2b; OP2b).

In this study we examine the remains of stratigraphic unit (SU) 193 of Pit 40. While this is not the whole sample, it accounts for $\sim 60 \%$ of the whole sample and $\sim 80 \%$ of Phase 1 (see Error! Reference source not found.) and so it provides critical information about the funerary behaviours associated with Pit 40 and adopted in recent prehistory, thus enhancing our knowledge about these past populations and providing information to guide future studies. Further, ongoing analysis of the remaining sample reveals no meaningful differences between contexts, and so expanding the sample is unlikely to impact our interpretations.

One of the most common and critical questions regarding contexts involving burned skeletal remain is related to the pre-burning condition of the remains. This is because burning of dry bones implies a complex multistage sequence of funerary rites that burning of complete bodies (i.e. cadavers) may not. Thus we aim to infer if the cremated remains from Pit 40 correspond to the outcome of i) exclusive cremations of complete bodies, ii) exclusive cremations of dry and disarticulated skeletons or iii) both (as has been hypothesised for Pit 16, Ambiente 1 and Cista). To that end, we attempted to infer the pre-burning condition of the remains using heat-induced bone changes and archaeothanatological and taphonomic data. Also, to better outline the vast spectrum of cremation-related funerary practices adopted during this chronological period in the current Portuguese territory, we compared our results with those from the coeval contexts of the contexts associated with Pit 40 (Ambiente 1 and Cista), Pit 16 of Perdigões and OP2b (for which comprehensive anthropological studies have been undertaken).

\subsection{The Perdigões and Pit 40 archaeological context}

Located in the municipality of Reguengos de Monsaraz, Évora district, in South Portugal, Perdigões is a large ditched enclosure that has been investigated for the last 21 
years, in a long term program of research led by the Archaeological Research Group (NIA) of ERA Arqueologia S.A., and has an extensive list of publications (Valera 2017a). It comprises a set of ditched enclosures (and thousands of pits) with a long period of construction and use, and is implanted in a natural amphitheatre open to the East. The actual image is one of a progressive but arrhythmic growth, starting with smaller enclosures in the centre of the natural amphitheatre at the late Middle Neolithic, followed by an accelerated enlargement of the enclosed area during the Late Neolithic/transition to the Chalcolithic, in the early $3^{\text {rd }}$ millennium BC, until the site is abandoned around 2000 BC. During this time span, funerary practices and body manipulation were always present, but revealing diversified procedures: primary depositions in pits (rare) and secondary depositions in ditches and in several funerary structures. Pit 40 is one of these structures.

Pit 40 is a circular pit with $2.5 \mathrm{~m}$ diameter and $0.50 \mathrm{~m}$ deep, located in the central area of Perdigões ditched enclosures. It presents two post holes in the centre, so it must have had a roof in perishable materials and recent excavations suggest it may have had a wood passage. Therefore, this feature was intentionally built to function as a tomb, thus not corresponding to a reused pit. It was used for successive secondary depositions of mostly human cremated remains (three phases of deposition were detected) which were commingled (although some partially articulated remains were also found; Figure 1). Associated with the human remain, burned faunal remains and votive materials, where ivory anthropomorphic schematic and naturalistic figurines and marble betiles punctuate were also found (Valera 2015; Valera and Evangelista 2014; Valera et al. 2014). Several radiocarbon dates under publication place this context in the middle of the $3^{\text {rd }}$ millennium BC (2600-2400).

\section{Materials and methods}

The study of the cremains of Pit 40 is currently underway. Here we present the results from a recently fully examined stratigraphic unit (SU 193; integrated in phase 1 of the depositions) and compare it with the results of another study that fully examined other stratigraphic contexts located just next to Pit 40 (Ambiente 1 and Cista; see above; Pereira, 2015). Altogether, these represent approximately $75 \%$ of the full sample from Pit 40 and associated outer contexts. We further compared the results from Pit 40 to other similar funerary contexts; Pit 16 also from Perdigões (Silva et al. 2015b), and the 
burned human remains from OP2b (Silva et al. 2008). The latter is a Chalcolithic tholos connected to the corridor of the Dolmen of Olival da Pega 2, $15 \mathrm{~km}$ distant from Perdigões, from which skeletal remains were recovered. Of those, a small subset displays heat-induced changes which were originally interpreted as the result of a sanitization process of OP2b (Gonçalves 1999; Gonçalves 2003).

Because of the size of the sample from Pit 40, it was not possible to perform a systematic inventory of each bone fragment. As such, we inventoried bone fragments that hold relevant information for the estimation of the minimum number of individuals (MNI), age-at-death, sex and paleopathology. In such cases, an individual inventory number was allocated to each fragment, the fragment was anatomically identified and information about heat-induced changes and paleobiology was systematically recorded. All data and interpretation about heat-induced changes and paleobiology were thus based on the inventoried bones. When the fragments did not present relevant information for the above mentioned variables, they were identified by bone whenever possible or anatomical category when specific bone identification was not possible. When fragments were too small to be allocated to an anatomical region they were classified as unidentified.

To infer the pre-burning condition of the remains, we analysed five parameters that are theoretically correlated to it: i) proportional mass of anatomical regions; ii) frequency of specific bones of labile joints; iii) heat-induced colour pattern; iv) frequency of heat-induced fractures; and v) frequency of heat-induced deformation (i.e., warping).

Because SU 193 accounts for the majority of the full sample of Pit $40(\sim 60 \%)$ and no meaningful differences exist between this $\mathrm{SU}$ and other contexts of the ongoing study, the results presented are considered representative of the whole sample. Nonetheless, future publications will address this prediction.

\subsection{Proportional mass of anatomical regions}

This approach is based on the premise that atypical representativeness of anatomical regions is more likely in cremation of dry skeletons than in cremation of bodies with soft tissues. This is because in the latter the soft tissues preserve the bones in their anatomical location when the body is handled and so bone loss or selection is 
theoretically minimized. Conversely, this may not be the case in dry skeletons and so bone loss, or deliberate selection, is more likely. Specifically, if fleshed bodies are cremated bone loss or selection is likely after cremation, (i) during recollection of the remains from the pyre and transport to the final depositional site and (ii) the use of the final deposition site, which may include removal of sediments and bones. If dry bones are cremated, bones may be lost or selected during these processes and also before cremation, when the bones are recovered from their original depositional place. Thus, the probability of changing the natural representativeness of anatomical regions is higher when burning dry remains than when burning bodies with soft tissues.

Proportional mass of different anatomical regions was used here to assess skeletal representativeness (Silva et al. 2009). To that end, each bone fragment is usually allocated to anatomical categories (e.g. head; trunk; limbs; limb extremities) and each of these is weighed. Because a large portion of bone fragments could only be identified as fragments of diaphyses of long bones, we favoured the use of an overall category of limbs instead of two separated categories for upper limbs and lower limbs (even though bones were identified according to that classification whenever possible). To provide more resolution to the analysis, we also weighed the first distal phalanges of the feet separately. These phalanges are relatively easy to identify and are part of a labile joint. As such, a proportional mass of the first distal phalanges of the feet comparable to reference studies is most likely if cremation of fleshed remains occurred. Bone fragments that were not identifiable due to their reduced size were classified as unidentified. Proportional mass was then compared with the expected proportions calculated via regression equations developed by Gonçalves et al. (2015a). The proportional mass of the first distal phalanges of the foot of Pit 40 were compared to reference values obtained on a sample of 12 unburned skeletons ( 5 females and 7 males) from the $21^{\text {st }}$ Century Identified Skeletal Collection of the University of Coimbra (Ferreira et al. 2014). This was carried out to determine if atypical proportional mass was present, which may have resulted from pre or post-burning selection of anatomical regions (intentional or non-intentional). 


\subsection{Bone frequency}

The atypical frequency of specific skeletal elements may relate to the funerary rite and thus this criterion has been previously used to infer primary vs secondary depositions (Andrews and Bello 2006; Bello and Andrews 2006; Duday and Guillon 2006; Gonçalves et al. 2016; Roksandic 2002). This is because secondary depositions often involve deliberate selection of specific skeletal elements (e.g. crania and long bones) or because collection and transport of skeletal elements often occur after decomposition, hence resulting in the loss of small bones from labile joints such as the ones from the hands and feet (Duday 2006; Duday and Guillon 2006; Roksandic 2002). Thus, larger frequencies of these skeletal elements are more likely in primary than in secondary depositions.

While the cremation deposits in pit 40 are clearly secondary, small differences between the most frequent bone and bones that are commonly poorly represented even in primary depositions may suggest cremation of fleshed individuals and not of fully skeletonised bones. Thus, the frequency of the most frequent skeletal element was compared to that of the first distal phalange of the foot. The latter was chosen because i) it integrates a labile joint and so is likely to be lost in secondary depositions; ii) it is one of the most poorly represented bones in primary burials (Bello and Andrews 2006; Waldron 1987); iii) it is relatively easy to identify; and iv) preserves well whenever present. The frequency of the first distal phalange of the foot was calculated in function of the MNI. To that end, individually identifiable bone fragments were inventoried and the MNI estimated is based on the Minimum Number of Elements (MNE). Thus, the most frequent element corresponds to the MNI (Robb 2016). Differences in frequency were then interpreted based on studies that quantify the representativeness of this bone in primary burials (Bello and Andrews 2006; Waldron 1987).

\subsection{Heat-induced changes}

When exposed to heat, bone undergoes several stages of transformation that lead to heat-induced changes in colour (Ellingham et al. 2015; Munro et al. 2007; Shipman et al. 1984), formation of fractures (Binford 1963; Buikstra and Swegle 1989; Gonçalves et al. 2011; Spennemann and Colley 1989; Whyte 2001) and warping 
(Binford 1963; Buikstra and Swegle 1989; Gonçalves et al. 2011). We analysed such changes because they have been related to the pre-burning condition of the bones.

\subsubsection{Heat-induced colour changes}

Exposure to heat leads to colour changes that are correlated with burning temperature (Shipman et al., 1984; Etxeberria, 1994; Mayne Correia, 1997; Devlin and Herrmann, 2008; Walker et al., 2008; but see Walker et al. (2008) and Reidsma et al. (2016), who show similar heat-induced colours may occur when bones are burned at different temperatures due to differences in oxygen availability and duration of exposure to heat). Thus, heat-induced colour changes were used to tentatively infer the intensity of the cremation. Most important, to infer the pre-burning condition of the remains, heat-induced colour changes were compared in the internal and external surface of bones to determine if they might have been fragmented before burning. Thus, evidence of burning at higher temperatures in the internal surface than on the external surface of bones probably relates to pre-burning fragmentation, which is most likely in skeletonised remains. To tentatively approximate the intensity of burning, the scale of Buikstra and Ubelaker (1994) was used.

\subsubsection{Heat-induced fractures}

Exposure of bone to heat leads to changes in size (usually in the form of shrinkage) and formation of different fractures, including curved, linear, patina and delamination (Binford 1963; Buikstra and Swegle 1989; Gonçalves et al. 2011). Although early studies suggest curved fractures only occur in fleshed/wet bone (Binford 1963), several authors demonstrated that this type of fractures may also occur in dry bones and so it is not a conclusive indicator of the pre-burning condition of bones (Gonçalves and Pires 2016; Gonçalves et al. 2011). Yet, such fractures occur more frequently in bones burned with soft tissues than in completely skeletonised remains (Gonçalves et al. 2011). Thus, we quantified the presence of curved fractures relative to other types of heat-induced fractures (linear, patina and delamination). 


\subsubsection{Warping}

When exposed to heat, bones may warp. Although this morphological change has, for quite some time, been said to occur only in wet or fleshed bones (Baby 1954; Binford 1963; Etxeberria 1994), it has also been identified in dry cremated bones (Gonçalves et al. 2015b; Gonçalves et al. 2011; Vassalo et al. 2016; Vassalo et al. 2017). Thus, presence/absence of warping is an inconclusive indicator of the preburning condition of bones (Gonçalves et al. 2011). Yet, warping is more frequent in bones that were burned after being buried for shorter periods than in bones burned after being buried for longer periods (Vassalo et al. 2016), and so high frequencies of warping may reflect absence or short periods of burial before cremation. Here we quantify the presence of warping and use its frequency to infer if bones were likely buried for long periods prior to cremation.

\section{Results}

\subsection{Proportional mass}

A total of $137 \mathrm{~kg}$ of bone was sorted by anatomical category. Because $38 \mathrm{~kg}$ were unidentified, the regression equations to predict the expected proportions of each anatomical region were implemented using a $72 \%$ value for the part of anatomically identified bone fragments (corresponding to $99 \mathrm{~kg}$ of bone).

Table 1 shows the proportional mass of the different skeletal regions of the skeletal remains from pit 40 is within the intervals estimated using the regressions of Gonçalves (2015a), which account for the predicted mass of each region taking into account the presence of anatomically unidentified bone fragments. Thus, the results suggest no atypical proportional mass in any of the anatomical regions. When applying the regressions of Gonçalves (2015a), the proportional mass of Ambiente 1 is within the predicted range. Nonetheless it should be mentioned that the original study of Ambiente 1 presents different anatomical categories, which had to be converted to the ones used in this study. Specifically, Pereira (2015) uses skull, hands/feet, long bones, other bones (which includes vertebrae, ribs and flat bones) and unidentified. Thus, to render the results comparable, the category 'other bones' was converted into trunk because it includes vertebrae and ribs. While probably not meaningful, this inevitably overestimates the proportional mass of the trunk and underestimates that of the limbs, 
because this category also includes flat bones (which in this study are allocated to limbs).

The mean proportional mass of the two first distal phalanges of the foot in function of the total skeletal mass was $0.03 \%$, thus slightly lower than the $0.05 \%$ (S.D.: 0.01 ) derived from the reference sample (minimum: 0.04\%; maximum: 0.07\%).

\subsection{Bone frequency}

The most frequent bone element from SU 193 was the right pars petrosa $(n=147)$, followed by the left pars petrosa $(n=144)$ and the left $(n=71)$ and right $(n=70)$ mandibular condyles. In the study of Pereira (2015) the right pars petrosa was also the most frequent element $(n=77)$, followed by the left pars petrosa $(n=43)$, the right mandibular condyle $(n=29)$ and the left mandibular condyle $(n=28)$.

We favoured not siding the first distal phalange of the foot because this is not always straightforward. We also only selected the distal phalange and not the proximal as well because the latter is less dense, and so more prone to heat induced fragmentation (as was clear during the cleaning of the bones) and so less represented/identifiable in the sample. Because there were 147 right petrosals and 54 distal phalanges of the first digit (thus meaning that at least 27 are necessarily from the same side) the frequency of the latter was larger than $18 \%$ when compared to the most frequent skeletal element in the sample. Waldron (1987) reported frequencies of $11-13 \%$ for the left and right phalanges of the first digit of the foot in the primary burials of 88 adult individuals from the Romano-British site at West Tenter Street (London). That study did not specify the values of the proximal and distal phalanges (and so the frequency of the distal phalange is most probably lower than the $11-13 \%$ because it is smaller and more difficult to preserve/retrieve, while that of the proximal phalange is most probably higher), and so we assume the frequency found in SU193 of Pit 40 was considerably higher than that observed by Waldron (1987). Bello and Andrews (2006) provided frequency intervals for the distal phalange of the first digit of the foot in two primary burial sites. Unfortunately, reported frequencies were given in somewhat large intervals corresponding to $1 \%-24 \%$ and $25 \%-49 \%$ in St. Estève le Pont ( $8^{\text {th }}$ Century AD) and in Observance (1722 AD), respectively. Therefore, the frequency in unit 193 of Pit 40 was comparable or higher than in St. Estève le Pont and lower than in Observance. Regrettably, no reports are currently available for large assemblages of primary 
cremations, so our comparisons are tentative. Our results were not compared to Ambiente 1, Cista, Pit 16 and OP2 because this analysis was not undertaken in those studies.

\subsection{Heat-induced colour changes}

Analysis of the heat-induced colour changes suggests most remains were cremated at generally high temperatures and only a residual part of the remains did not display this heat-induced feature suggesting they were not burned. Most observable internal surfaces of bones did not display evidence of burning at higher temperatures than the external surfaces. Nonetheless, several bone fragments (mainly cranial) displayed evidence of burning at higher temperatures in the internal surface than on the external surface (Figure 2).

\subsection{Heat-induced fractures}

Of the 4516 inventoried bone elements, 1519 (34\%) displayed clearly visible heat-induced macro-fractures. Of the latter, only a small percentage displayed curved fractures (6\%; Figure 3), which were almost absent in bone elements of the trunk and were most frequent in bones of the head (Figure 4).

In Ambiente 1 and Cista, 7\% of the bones displayed heat-induced fractures, and $12 \%$ of those presented curved fractures (Pereira 2015). In OP2, 39\% of the sample displayed heat-induced fractures, of which 19\% were curved (Silva et al. 2008). In Pit 16 , coexistence of different fractures is reported, but no quantification of results was performed (Silva et al. 2015b).

\subsection{Warping}

Only 150/4516 (3\%) of the inventoried bone elements displayed warping (Figure $5)$, which was most frequent in bones of the head $(61 / 1430=4 \%)$ followed by bones of the limbs $(86 / 2708=3 \%)$ and almost absent in bones of the trunk $(3 / 378=1 \%)$. 
In OP2b, $8 \%$ of the sample displayed warping (Silva et al. 2008). No such data is reported for the nearby Ambiente 1 and Cista (Pereira 2015) and Pit 16 (Silva et al. 2015b).

\section{Discussion}

SU 193 of Pit $40(\mathrm{MNI}=147)$ and associated outer contexts $(\mathrm{MNI}=77)$ of Perdigões present an unparalleled total high number of cremated individuals $(\mathrm{N}=224)$ in an archaeological context of this chronology. If we further include data of the ongoing study, Pit 40 alone includes 240 left and 239 right petrosals. Thus, Pit 40 and associated contexts total a minimum number of 316 individuals, largely surpassing the comparable nearby funerary contexts of Pit 16 of Perdigões $(\mathrm{MNI}=9)$ and $\mathrm{OP} 2 \mathrm{~b}(\mathrm{MNI}=16)$. Further, it also largely surpasses the MNI of comparable contexts from other countries as well, such as Dolmen 2 in San Sebastian (which, to the best of our knowledge, is the next archaeological structure with a commingled collective burial containing the highest minimum number of cremated individuals of this chronology $(\mathrm{N}=78$; Gatto, 2007). Regardless, the combined analyses of the five criteria we assessed, which are relatively correlated with the pre-burning condition of the remains, provide somewhat conflicting results regarding the pre-burning condition of the human remains

\subsection{The pre-burning condition of the skeletal remains from Pit 40}

Despite a conclusive assessment of the pre-burning condition of skeletal remains is very difficult to attain, our results, combining several approaches, suggest most remains were likely cremated while fleshed, although this practice probably coexisted with secondary cremations, i.e., the burning of fully skeletonised remains.

The proportional mass of different skeletal regions suggests cremation of fleshed individuals. This is because the proportional mass found in Pit 40 is generally consistent with regression predictions (Gonçalves et al. 2015a). Thus, selection of different regions such as crania and long bones, as would be more probable in fully skeletonised remains, is unlikely. While the anatomical categories we used (head, trunk, limbs) may lack resolution for this analysis because they lump several bones in single anatomical regions, the proportional mass of the first distal phalange of the foot, which is part of a labile joint, is also generally consistent with burning of fleshed remains. First phalanges 
are small and so their full recovery from a cremation pyre after burning (which causes size changes, deformation and fragmentation) is a quite difficult and unlikely task. Therefore, its high representation in SU 193 is not supportive of an interpretation of this context as being mainly the result of secondary cremations. Moreover, the frequency of this bone also approximates that found in some primary burial sites and so appears to suggest cremation of fleshed rather than skeletonised remains. Additionally, we identified bones that are very small, such as distal phalanges of feet, hyoids, epiphyses of metacarpals and metatarsals, sesamoids and unfused centra of vertebrae. Because such bones are extremely small and difficult to retrieve, this appears most likely as a result of burning of fleshed remains. However, they were collected after cremation and transported and deposited in Pit 40 with the rest of skeletal remains, showing a significant care in the process and documenting that their presence in a funerary contexts cannot axiomatically be ascribed to primary depositions. Lastly, several partially articulated remains were found (Figure 1), including a lower limb, two upper limbs, a head and partial trunk, a thoracic vertebral segment, and a cremated right temporal bone with the right mandibular condyle still in the glenoid fossa (Figure 6). While only the latter shows unequivocal heat-induced bone changes (although absence of heat-induced macroscopic bone changes in the other remains does not preclude low intensity burning), such partial anatomical connections evidence the clear deposition of fleshed remains in Pit 40.

Most bones evidenced heat-induced colour changes suggestive of burning at high temperatures. Most such changes are suggestive of burning at higher temperatures of the external surfaces than of the internal surfaces of bones. While this is consistent with burning of whole bones (and so possibly cadavers), the presence of a minority of cranial bones evidencing burning at higher temperatures of the internal surfaces suggests otherwise. This is because, during the soft tissue pyrolysis caused by cremation, the outer tabula tends to become exposed sooner to heat than the inner tabula (Bohnert et al. 1998). In consequence, the latter tends to present signs of less intense exposure. The small portion of bones displaying the inverse colour pattern thus supports the interpretation of SU 193 being the result of cremation practices targeting remains in different stages of decomposition, with an emphasis on primary cremation. As an additional element of support, while most bones from Pit 40 presented no signs of erosion, some displayed non heat-induced erosion of the periosteal and endosteal surfaces, suggesting pre-burning deposition/burial (Figure 7). 
While the interpretation of the above mentioned criteria appear to be relatively straightforward and useful for the estimation of the pre-burning condition of remains, the interpretation of heat-induced curved fractures and warping is less clear. In Pit 40, only $6 \%$ of the inventoried bones with heat-induced fractures show curved fractures and only $3 \%$ of the inventoried bones displayed warping. In their study comparing the frequency of heat-induced curved factures between cremated cadavers and dry bones, Gonçalves et al. (2015b) report curved fractures in $96 \%$ of the cadavers and $22 \%$ of dry skeletons. Vassalo et al. (2016) compared the frequency of heat-induced warping between bones cremated after buried for less than 20 years and bones cremated after being buried for at least 80 years. The former displayed warping in 67\% of the cases and the latter in $18 \%$. Yet, the study of Gonçalves et al. (2015b) quantifies heat-induced curved fractures per individual, the study of Vassalo et al. (2016) quantifies warping per bone and the results of this study for Pit 40 inevitably quantify both per bone fragment (due to extreme fragmentation and commingling of a minimum of 147 individuals). Thus, while our results of heat-induced curved fractures and warping appear more consistent with burning of dry skeletons, differences in quantification methodology prevent a direct comparison of results and so our results are inconclusive due to lack of appropriate comparative reference studies. This is consistent with the conclusions of Gonçalves et al. $(2011 ; 2015 b)$ that, on their own, curved fractures and warping are not very useful indicators of the pre-burning condition of skeletal remains, especially when used to assess contexts with multiple individuals.

Thus, most criteria used in this research suggest SU 193 was mainly composed of elements resulting from the burning of fleshed remains. However, the presence of some bones with eroded surfaces and evidencing burning at higher temperatures of the internal surfaces than of the external ones also suggests that a smaller part of the assemblage resulted from the burning of skeletonised remains. This cremation diversity adds to the apparent inclusion of skeletal remains not subjected to burning. As such, Pit 40 reveals the adoption of very different body treatments by this population (consistent with the funerary diversity in the whole Perdigões enclosure). Such diversity may reflect different belief systems, which is commonly observed within segmented communities, different stages of complex multistage funerary rites, or even different procedures according to social status. 


\subsection{Comparison of Pit 40 and other coeval contexts}

Results from Pit 40 are generally comparable to the other cremation contexts from Perdigões, which evidence intentional cremation of the human remains with subsequent retrieval of the cremains and transport to a final secondary deposition place. Further, all contexts have been suggested to include cremations of individuals in different stages of decomposition (although mainly of fleshed individuals).

The results from all cremation contexts from Perdigões contrast with those from OP2b. In that tholos, only a minority of the bones were burned and most evidence burning at low temperatures (Silva et al. 2008). Thus, researchers have suggested the human remains were burned inside the tholos to sanitize the structure rather than intentional cremation of human remains (Gonçalves 1999; Gonçalves 2003). In fact, most bones (61\%) display evidence of no burning or burning at low temperatures (Silva et al. 2008), which may in fact suggest funerary differences in the burning process of $\mathrm{OP} 2 \mathrm{~b}$ and the cremation contexts from Perdigões. The latter probably consist mainly of primary cremations commingled with secondary cremations and, in Pit 40, with articulated remains that have apparently not been exposed to heat.

The main differences between Pit 40 and the other cremation contexts from Perdigões is the unparalleled high MNI, which in SU 193 is 147, in Ambiente 1 and Cista is 77, in Pit 16 is 9 and in OP2b is 16 (although the MNI in OP2b only includes the burned remains, thus excluding the majority of the sample). The other is that all remains from Pit 16 were reported to show heat-induced changes, while in Pit 40, Ambiente 1 and Cista a minority did not display heat-induced colour changes (despite the majority showing evidence of burning at high temperatures; also, this does not exclude incomplete burning or at low temperatures which caused no macroscopic heatinduced bone changes). In contrast, most of the human remains from OP2b were unburned.

\section{Acknowledgements}

The authors acknowledge the financial support from the Portuguese Foundation for Science and Technology (SFRH/BPD/84268/2012; PTDC/EPH-ARQ/0798/2014; PTDC/IVC-ANT/1201/2014 \& POCI-01-0145-FEDER-016766; PEst- 
OE/SADG/UI0283/2013). This research is part of the Global Archaeological Research Program of Perdigões, directed by Era Arqueologia.

\section{Declaration of interest statement}

The authors declare no competing interests. 


\section{References}

Andrews P, Bello S (2006) Pattern in human burial practice. In: Gowland R, Knüsel C (eds) Social archaeology of funerary remains. Oxbow, Oxford, pp 1429

Baby RS (1954) Hopewell cremation practices. vol 1. Ohio Historical Society,

Bello S, Andrews P (2006) The intrinsic pattern of preservation of human skeletons and its influence on the interpretation of funerary behaviours Social archaeology of funerary remains: $1-13$

Binford LR ( 1963) An analysis of cremations from three Michigan sites Wis Archaeol 44:98-110

Bohnert M, Rost T, Pollak S (1998) The degree of destruction of human bodies in relation to the duration of the fire Forensic Science International 95:11-21 doi:https://doi.org/10.1016/S0379-0738(98)00076-0

Buikstra J, Ubelaker D (1994) Standards for Data Collection from Human Skeletal Remains: Proceedings of a Seminar at the Field Museum of Natural History. Arkansas Archeological Survey, Fayetteville

Buikstra JE, Swegle M (1989) Bone modification due to burning: experimental evidence

Cataroche J, Gowland R (2015) Flesh, fire, and funerary remains from the Neolithic site of La Varde, Guernsey: Investigations past and present. In: Thompson T (ed) The Archaeology of Cremation: Burned human remains in funerary studies. Oxbow Books, Oxford, pp 19-42

Corrêa AAM, Teixeira C (1949) A jazida pré-histórica de Eira Pedrinha: Condeixa. Direcção Geral de Minas e Serviços Geológicos, Serviços Geológicos de Portugal, Lisboa 
de Becdelievre C, Thiol S, Saligny L, Granjon L, Rottier S (2016) The role of fire within Neolithic collective burials: Spatial analyses of cremains from the site of La Truie Pendue, France Journal of Field Archaeology 41:550-567 doi:10.1080/00934690.2016.1219209

de Becdelievre C, Thiol S, Santos F, Rottier S (2015) From fire-induced alterations on human bones to the original circumstances of the fire: An integrated approach of human cremains drawn from a Neolithic collective burial Journal of Archaeological Science: Reports 4:210-225 doi:https://doi.org/10.1016/j.jasrep.2015.08.030

Duday H (2006) Archaeoetnoanatology or the archaeology of death. In: Gowland RL, Knüssel C (eds) Social Archaeology of funerary remains. Oxbow Books, Oxford, pp 30-56

Duday H, Guillon M (2006) Understanding the Circumstances of Decomposition When the Body Is Skeletonized. In: Schmitt A, Cunha E, Pinheiro J (eds) Forensic Anthropology and Medicine: Complementary Sciences From Recovery to Cause of Death. Humana Press, Totowa, NJ, pp 117-157. doi:10.1007/978-1-59745-099-7_6

Ellingham STD, Thompson TJU, Islam M, Taylor G (2015) Estimating temperature exposure of burnt bone - A methodological review Science \& Justice 55:181-188 doi:http://dx.doi.org/10.1016/j.scijus.2014.12.002

Etxeberria F (1994) Aspectos macroscópicos del hueso sometido al fuego. Revisión de las cremaciones descritas en el País Vasco desde la Arqueología Munibe Ciencias naturales 46:111-116

Fernández-Crespo T, de-la-Rúa C (2016) Demographic differences between funerary caves and megalithic graves of northern Spanish Late Neolithic/Early Chalcolithic Am J Phys Anthropol 160:284-297 doi:10.1002/ajpa.22963 
Fernández-Crespo T, Schulting RJ (2017) Living different lives: Early social differentiation identified through linking mortuary and isotopic variability in Late Neolithic/ Early Chalcolithic north-central Spain Plos One 12:e0177881

Ferreira MT, Vicente R, Navega D, Gonçalves D, Curate F, Cunha E (2014) A new forensic collection housed at the University of Coimbra, Portugal: The 21st century identified skeletal collection Forensic Science International 245:202.e201-202.e205 doi:http://dx.doi.org/10.1016/j.forsciint.2014.09.021

Fontanals-Coll M, Subirà ME, Bonilla MD-Z, Duboscq S, Gibaja JF (2015) Investigating palaeodietary and social differences between two differentiated sectors of a Neolithic community, La Bòbila Madurell-Can Gambús (north-east Iberian Peninsula) Journal of Archaeological Science: Reports 3:160-170 doi:https://doi.org/10.1016/j.jasrep.2015.06.013

Gatto E (2007) La crémation parmi les pratiques funéraires du Néolithique récent-final en France Méthodes d'étude et analyse de sites Bulletins et Mémoires de la Société d'Anthropologie de Paris:195-220

Geber J, Hensey R, Meehan P, Moore S, Kador T (2017) Reassessing the Age, Sex and Metric Variation of Commingled Human Remains from a 1911 Excavation of a Neolithic Passage Tomb Complex in North-West Ireland Int J Osteoarchaeol 27:131-142 doi:10.1002/oa.2521

Gonçalves D, Campanacho V, Thompson T, Mataloto R (2015a) The weight of the matter: Examining the potential of skeletal weight for the bioarchaeological analysis of cremation at the Iron Age necropolis of Tera (Portugal). In: Thompson T (ed) The Archaeology of Cremation: burned human remains in funerary studies, vol 8. Oxbow Books, Oxford, pp 63-96

Gonçalves D, Cunha E, Thompson TJU (2015b) Estimation of the pre-burning condition of human remains in forensic contexts Int J Legal Med 129:1137-1143 doi:10.1007/s00414-014-1027-8 
Gonçalves D, Granja R, Alves-Cardoso F, Carvalho AF (2016) All different, all equal: Evidence of a heterogeneous Neolithic population at the Bom Santo Cave necropolis (Portugal) HOMO - Journal of Comparative Human Biology 67:203215 doi:http://dx.doi.org/10.1016/j.jchb.2015.12.004

Gonçalves D, Pires AE (2016) Cremation under fire: a review of bioarchaeological approaches from 1995 to 2015 Archaeol Anthropol Sci:1-12 doi:10.1007/s12520-016-0333-0

Gonçalves D, Thompson TJU, Cunha E (2011) Implications of heat-induced changes in bone on the interpretation of funerary behaviour and practice $J$ Archaeol Sci 38:1308-1313 doi:http://dx.doi.org/10.1016/j.jas.2011.01.006

Gonçalves VS (1999) Reguengos de Monsaraz, territórios megalíticos. Câmara Municipal de Reguengos de Monsaraz, Lisboa

Gonçalves VS (2003) Sítios," horizontes" e artefactos. Leituras críticas de realidades perdidas. Câmara Municipal de Cascais, Cascais

Hutchinson DL, Aragon LV (2002) Collective Burials and Community Memories: Interpreting the Placement of the Dead in the Southeastern and MidAtlantic United States with Reference to Ethnographic Cases from Indonesia. In: Archeological Papers of the American Anthropological Association, vol 11. vol 1. Blackwell Publishing Ltd, pp 27-54. doi:10.1525/ap3a.2002.11.1.27

López-Onaindia D, Coca M, Gibaja JF, Subirà ME (2017) Biological differences related to cultural variability during the Neolithic in a micro-geographical area of the Iberian Peninsula Archaeol Anthropol Sci doi:10.1007/s12520-017-05154

Munro LE, Longstaffe FJ, White CD (2007) Burning and boiling of modern deer bone: Effects on crystallinity and oxygen isotope composition of bioapatite phosphate Palaeogeography, Palaeoclimatology, Palaeoecology 249:90-102 doi:https://doi.org/10.1016/j.palaeo.2007.01.011 
Oliveira Jd (2000) O Megalitismo de Xisto da Bacia do Sever MontalvãoCedillo Muitas Antas Pouca Gente?, Actas do I Colóquio Internacional sobre Megalitismo, Trabalhos de Arqueologia 16:135-158

Pereira D (2015) Nas cinzas jazem engendros da morte, reflexos de vidas de outrora: As cremações pré-históricas dos Perdigões.

Reidsma FH, van Hoesel A, van Os BJH, Megens L, Braadbaart F (2016) Charred bone: Physical and chemical changes during laboratory simulated heating under reducing conditions and its relevance for the study of fire use in archaeology Journal of Archaeological Science: Reports 10:282-292 doi:https://doi.org/10.1016/j.jasrep.2016.10.001

Robb J (2016) What can we really say about skeletal part representation, MNI and funerary ritual? A simulation approach Journal of Archaeological Science: Reports 10:684-692 doi:https://doi.org/10.1016/j.jasrep.2016.05.033

Roksandic M (2002) Position of skeletal remains as a key to understanding mortuary behavior. In: Haglund WD, Sorg MH (eds) Advances in forensic taphonomy: method, theory, and archaeological perspectives. CRC Press, Boca Raton, FL, Florida, pp 99-117

Shipman P, Foster G, Schoeninger M (1984) Burnt bones and teeth: an experimental study of color, morphology, crystal structure and shrinkage J Archaeol Sci 11:307-325 doi:http://dx.doi.org/10.1016/0305-4403(84)90013-X

Silva A, Leando I, Valera A, Pereira D, Afonso C Late Neolithic pit burials from Perdigões enclosure (Portugal): preliminary results of the paleobiological analysis of the exhumed human bones. In: Death as Archaeology of Transition. Papers from the II International Conference of Transition Archaeology: Death Archaeology. Oxford: Archaeopress (BAR International Series, 2708), $2015 \mathrm{a}$.

Silva AM, Crubézy E, Cunha E (2009) Bone weight: new reference values based on a modern Portuguese identified skeletal collection Int J Osteoarchaeol 19:628-641 doi:10.1002/oa.998 
Silva AM, Garcia M, Leandro I, Evangelista LS, Rodrigues T, Valera AC (2017) Mortuary practices in Perdigões (Reguengos de Monsaraz, Portugal): bioanthropological approach to Tomb 2 JOURNAL OF ANDALUSIAN PREHISTORY 8

Silva AM, Leandro I, Pereira D, Costa C, Valera AC (2015b) Collective secondary cremation in a pit grave: A unique funerary context in Portuguese Chalcolithic burial practices HOMO - Journal of Comparative Human Biology 66:1-14 doi:http://dx.doi.org/10.1016/j.jchb.2014.10.003

Silva AM, Tereso S, Cruz C, Bettencourt AM (2013) The megalithic monument of Cabeço dos Moinhos (Brenha, Figueira da Foz): anthropological data.

Silva FC, Cunha E, Gonçalves V (2008) Sinais de fogo: análise antropológica de restos ósseos cremados do Neolítico final/Calcolítico do tholos OP2b (Olival da Pega, Reguengos de Monsaraz) Antropologia Portuguesa 24/25

Spennemann DH, Colley SM (1989) Fire in a Pit: The Effects of the Burning on Faunal Remains Archaeozoologia 3:51-64

Valera A (2015) The diversity of Ideotechnic objects at Perdigões Enclousure: a firts inventory of ítems and problems Arpi 3:238-256

Valera A, Godinho RM, Calvo E, Moro Berraquero J, Filipe V, Santos H Um mundo em negativo: fossos, fossas e hipogeus entre o Neolítico Final e a Idade do Bronze na margem esquerda do Guadiana (Brinches, Serpa). In: Silva AC, Regala FT, Martinho M (eds) $4^{\circ}$ Colóquio de Arqueologia do Alqueva - O Plano de Rega (2002-2010), Beja, 2010. EDIA, pp 55-73

Valera AC (2017a) Duas décadas de investigação nos Perdigões: resenha da bibliografia produzida Apontamentos de Arqueologia e Património 12:69-75

Valera AC The" exogenous" at Perdigões: approaching interaction in the late 4th and 3rd Millennium BC in Southwest lberia. In: Bartelheim M, Bueno Ramirez 
P, Kunst M (eds) Key resources and sociocultural developments in the Iberian chalcolithic, Tübingen, 2017b. Tübingen Library Publishing, pp 201-224

Valera AC, Evangelista LS (2014) Anthropomorphic Figurines at Perdigões Enclosure: Naturalism, Body Proportion and Canonical Posture as Forms of Ideological Language European Journal of Archaeology 17:286-300 doi:Doi: $10.1179 / 1461957114 y .0000000057$

Valera AC, Godinho RM (2010) Escavação arqueológica dos Perdigões (2017). Era Arqueologia, S.A., Lisboa

Valera AC, Schuhmacher TX, Banerjee A (2015) Ivory in the Chalcolithic enclosure of Perdigões (South Portugal): the social role of an exotic raw material World Archaeol 47:390-413 doi:10.1080/00438243.2015.1014571

Valera AC, Silva AM, Cunha C, Evangelista LS (2014) Funerary practices and body manipulation at Neolithic and Chalcolithic Perdigões ditched enclosures (south Portugal) Recent Prehistoric Enclosures and Funerary Practices in Europe:37-57

Vassalo AR, Cunha E, de Carvalho LAEB, Gonçalves D (2016) Rather yield than break: assessing the influence of human bone collagen content on heatinduced warping through vibrational spectroscopy Int J Legal Med 130:16471656 doi:10.1007/s00414-016-1400-x

Vassalo AR, Mamede AP, Ferreira MT, Cunha E, Gonçalves D (2017) The Gforce awakens: the influence of gravity in bone heat-induced warping and its implications for the estimation of the pre-burning condition of human remains Australian Journal of Forensic Sciences:1-8 doi:10.1080/00450618.2017.1340521

Waldron T (1987) The relative survival of the human skeleton: implications for palaeopathology. In: Boddington A, Garland AN, Janaway RC (eds) Death, Decay and Reconstruction: Approaches to Archaeology and Forensic Science. Manchester University Press, Manchester, pp 55-64 
Walker PL, Miller KWP, Richman R (2008) Time, temperature, and oxygen availability: an experimental study of the effects of environmental conditions on the color and organic content of cremated bone. In: Schmidt CW, Symes SA (eds) The Analysis of Burned Human Remains. Academic Press, San Diego, pp 129-136

Whyte TR (2001) Distinguishing Remains of Human Cremations from Burned Animal Bones Journal of Field Archaeology 28:437-448 doi:10.1179/jfa.2001.28.3-4.437 


\section{Figure captions}

Figure 1: Partially articulated skeletal remains in Pit 40 of Perdigões, deposited in the middle of the cremated remains of SU193. (A) General overview of the partially articulated skeletal remains and of Pit 40. (B) Detailed view of some of the partially articulated remains in A. (C) Computer Assisted Design (CAD) drawing of some of the partially articulated remains from Pit 40 .

Figure 2: Examples bone fragments with apparent lower burning exposure of the external surface (A) when compared to the internal surface (B).

Figure 3: Example of curved fractures in a long bone from SU 193 of pit 40.

Figure 4: Heat-induced fractures (curved vs other fractures) by anatomical region in SU 193 of pit 40.

Figure 5: Example of heat-induced warping in SU unit 193 of pit 40.

Figure 6: Right temporal bone with partially rotated right mandibular condyle in the glenoid fossa. Note the compatibility of the heat-induced changes of both bone fragments. This most likely reflects cremation of fleshed remains.

Figure 7: Example of erosion in the endocortical surface of a long bone from SU 193 of Pit 40 of Perdigões. 


\section{Table captions}

Table 1: Comparison of the mean proportional mass (in \%) of different skeletal regions from SU 193 with Ambiente 1, near Pit 40 (Pereira 2015) and the reference study of Silva et al. (2009). OP2 is not included in because that information was not included in the study. 

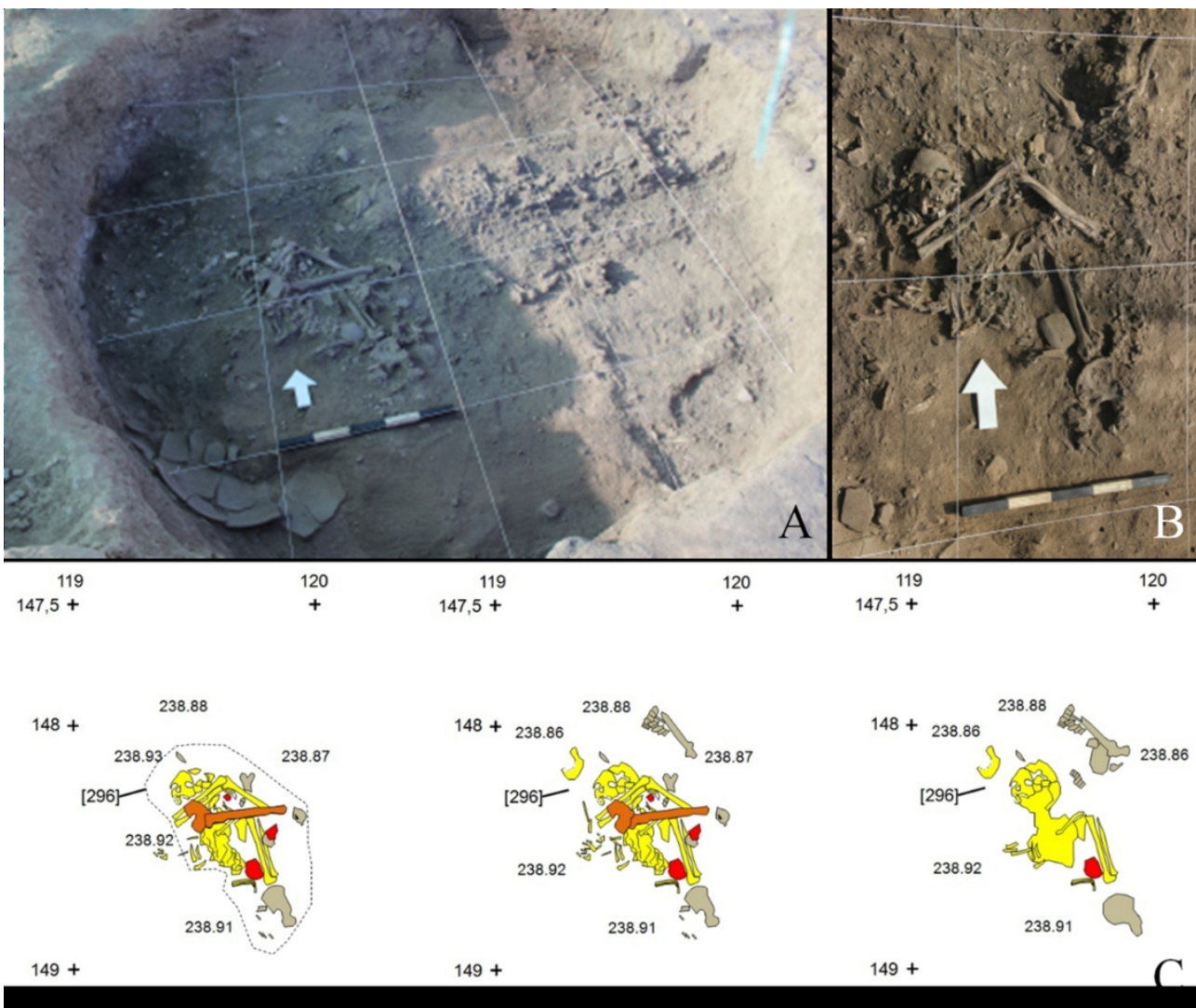

Figure 1: Partially articulated skeletal remains in Pit 40 of Perdigões, deposited in the middle of the cremated remains of SU193. (A) General overview of the partially articulated skeletal remains and of Pit 40.

(B) Detailed view of some of the partially articulated remains in A. (C) Computer Assisted Design (CAD) drawing of some of the partially articulated remains from Pit 40.

\section{$119 \times 99 \mathrm{~mm}(300 \times 300$ DPI $)$}


Figure 2: Examples bone fragments with apparent lower burning exposure of the external surface $(A)$ when compared to the internal surface (B). 


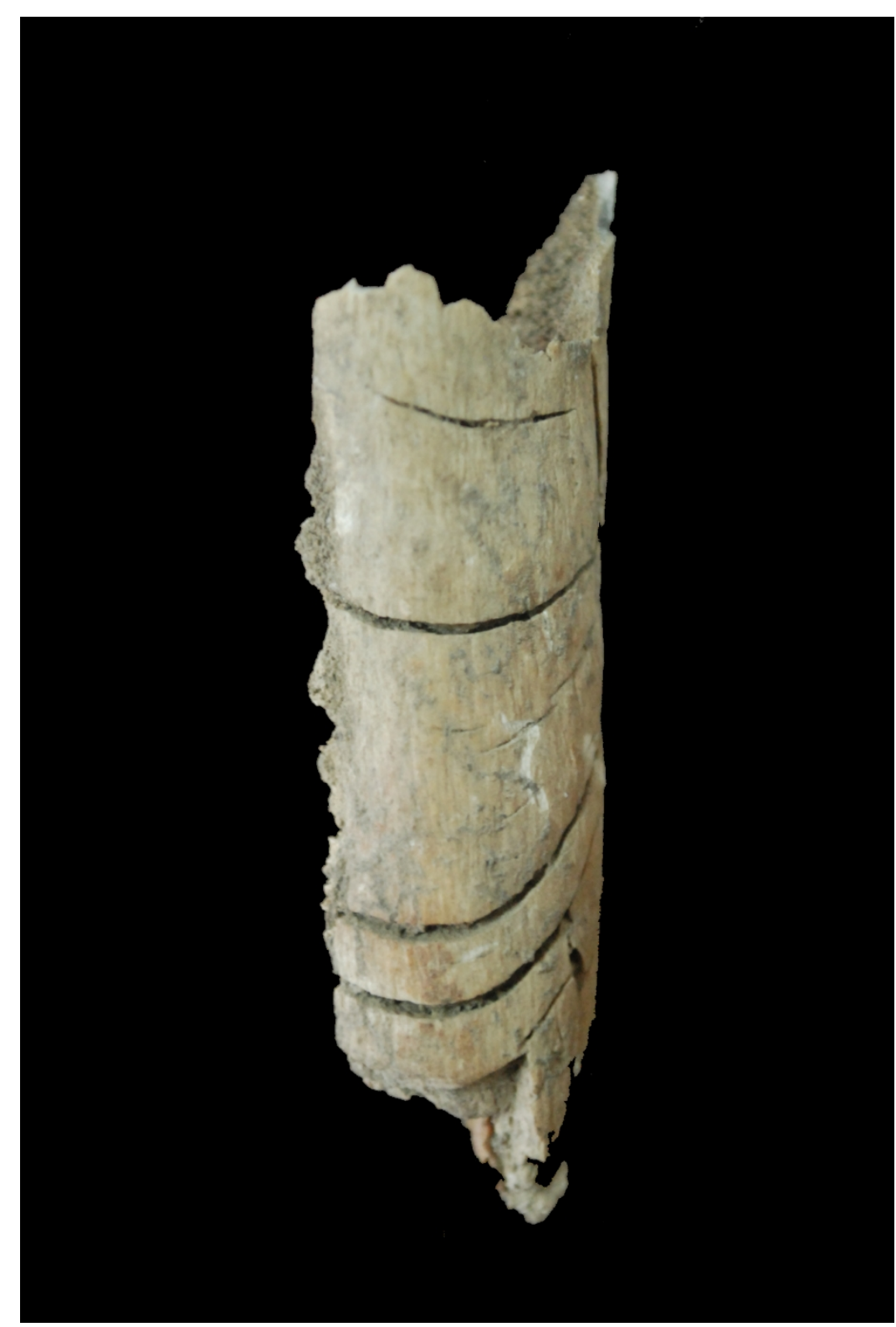

Figure 3: Example of curved fractures in a long bone from SU 193 of pit 40. 
Figure 4: Heat-induced fractures (curved vs other fractures) by anatomical region in SU 193 of pit 40.

$$
150 \times 90 \mathrm{~mm}(300 \times 300 \mathrm{DPI})
$$




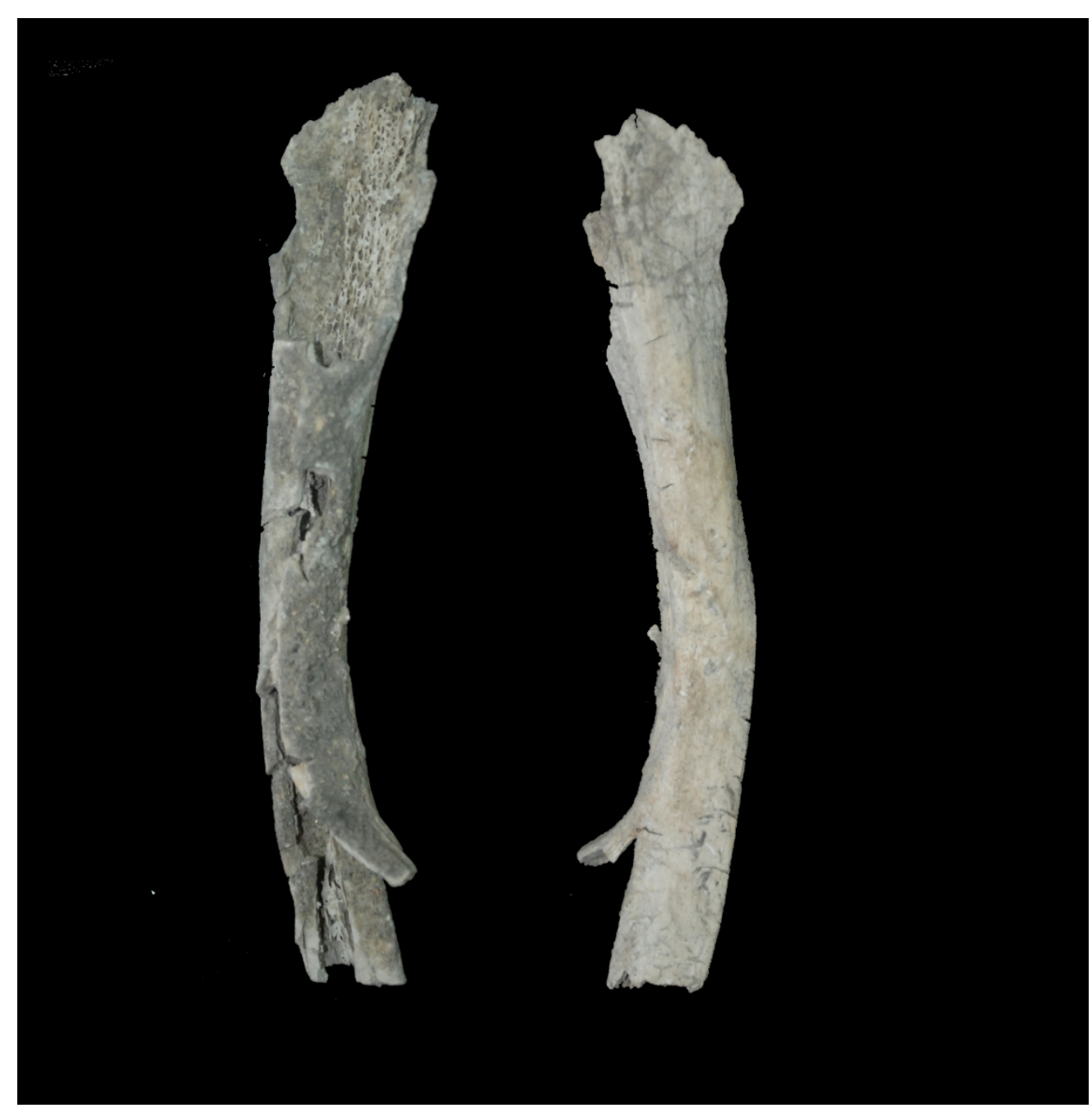

Figure 5: Example of heat-induced warping in SU unit 193 of pit 40. 
Figure 6: Right temporal bone with partially rotated right mandibular condyle in the glenoid fossa. Note the compatibility of the heat-induced changes of both bone fragments. This most likely reflects cremation of fleshed remains. 


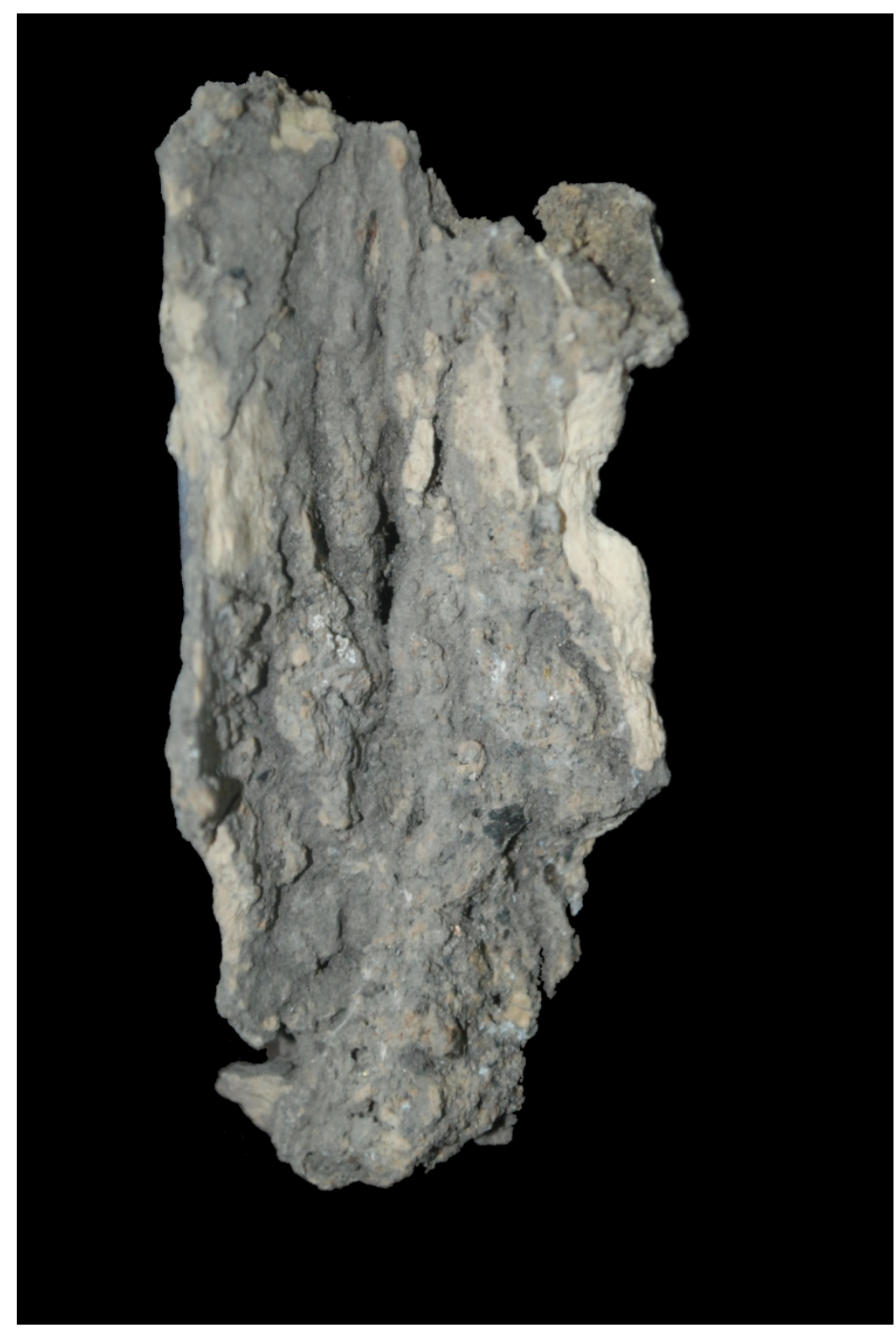

Figure 7: Example of erosion in the endocortical surface of a long bone from SU 193 of Pit 40 of Perdigões. 


\begin{tabular}{|c|c|c|c|c|}
\hline & Head & Trunk & Limbs & Unidentified \\
\hline Pit 40 & 18.98 & 8.10 & 45.35 & 27.57 \\
\hline $\begin{array}{l}\text { Predicted mass (Gonçalves et } \\
\text { al., 2015a) }\end{array}$ & $10.58-25.30$ & $8.26-12.60$ & $31.75-51.85$ & \\
\hline Silva et al. (2015; Pit 16) & 26.49 & 16.81 & 49.59 & 7.11 \\
\hline $\begin{array}{l}\text { Predicted mass (Gonçalves et } \\
\text { al., 2015a) }\end{array}$ & $12.48-29.70$ & $11.31-21.47$ & $43.50-67.01$ & \\
\hline Pereira (2015; Ambiente 1) & 25.28 & 13.95 & 42.73 & 18.04 \\
\hline $\begin{array}{l}\text { Predicted mass (Gonçalves et } \\
\text { al., 2015a) }\end{array}$ & $11.46-27.35$ & $9.68-19.06$ & $37.22-58.91$ & \\
\hline
\end{tabular}

